日植病報 $39: 246-250(1973)$

Ann. Phytopath. Soc. Japan 39 : 246-250 (1973)

\title{
Effect of Thiophanate-methyl on the Infection Process of Some Plant Pathogenic Fungi
}

\author{
Yasushi Yasuda*, Akira Nakata* \\ and Teruhisa NoguchI* \\ 安田 康*・中田 昭*・野口照久*：数種の植物病原菌の感染 \\ 過程におよぼすチオファネートーメチルの作用
}

\begin{abstract}
Effect of a new fungicide, thiophanate-methyl (Th-M) on the infection process of three fungi, Pyricularia oryzae, Colletotrichum lagenarium and Sphaerotheca fuliginea was investigated microscopically.

Th-M inhibited almost completely the development of hyphae of P. oryzae and C. lagenarium in host cells, whereas spore germination and appressorium formation were scarcely inhibited on the host treated with $500 \mathrm{ppm}$ Th-M. The growth of germ tube of $S$. fuliginea spore was also inhibited on $50 \mathrm{ppm}$ Th-M-treated cucumber leaves. Moreover, the swelling or breakage of spore and the distortion of germ tube of $P$. oryzae spore when directly contacted with $500 \mathrm{ppm}$ Th-M. On the other hand, the rice leaf sheath cells treated with Th-M revealed normal convex plasmolysis and the epidermal cell wall of treated cucumber leaves never showed morphological abnormality.

Methyl 2-benzimidazolecarbamate (MBC), a metabolite of Th-M also inhibited the development of invaded hyphae, but no difference between the effects of Th-M and MBC was observed in the infection process. It could be concluded that these acted characteristically rather in the process of penetration than in spore germination and appressorium formation on host cells.

(Received July 15, 1972)
\end{abstract}

\section{Introduction}

A new systemic fungicide, thiophanate-methyl (Th-M), dimethyl 4, 4'-o-phenylenebis (3-thioallophanate) has been recently found to be effective for the control of numerous fungal diseases of plants and its efficacy was curative as well as protective $\mathrm{e}^{3,4,5)}$. Th-M was reported to be converted into methyl 2-benzimidazolecarbamate $(\mathrm{MBC})$ in plants ${ }^{6,8}$, animals ${ }^{6}$ ) and fungi10). The mechanism of antifungal action of Th-M has been partially studied in connection with research of its metabolism ${ }^{10,12)}$, and it was found that $\mathrm{MBC}$ has more effective antifungal activity than that of Th-M. This paper reports the result of experiments on the effect of Th-M and $\mathrm{MBC}$ on the infection process of some phytopathogenic fungi, causing the rice blast disease, the anthracnose and the powdery mildew of cucumber.

\section{Materials and methods}

Hosts, inocula and inoculation Pyricularia oryzae Cav. was cultured on an oatmeal agar medium at $25 \mathrm{C}$ for 3 weeks. Five days after washing away old spores, newly formed ones on the medium were used as inocula. Inner epidermal tissues of rice leaf sheath (Oryza sativa L. cv.

* Nisso Institute for Life Science, Nippon Soda Co., Ltd., Oiso, Kanagawa, Japan. 日本曹達 (株) 生物科学研究所 
Kinmaze), about $7 \mathrm{~cm}$ in length were inoculated with spore suspension $\left(10^{6}-2 \times 10^{6} \mathrm{spores} / \mathrm{m} l\right)$ by Sakamoto's sheath inoculation method7), and incubated in Petri dish for given hours at 23-25 C. Colletotrichum lagenarium (Pass.) Elliss et Halsted was cultured on a potato sucrose agar at $24 \mathrm{C}$ for 6 days. The spore suspension $\left(10^{6}-10^{7} \mathrm{spores} / \mathrm{m} l\right)$ was dropped on the upper or lower epidermis of cucumber leaves (Cucumis sativus L. cv. Sagamihanjiro) treated with Th-M or MBC. The spores of Sphaerotheca fuliginea (Schlechtendahl) Pollacci which were obtained from heavily diseased cucumber leaves were dusted by using a hair brush on the lower surface of Th-M-injected leaves. The cucumber plants were incubated for given hours at $25 \mathrm{C}$.

Application of fungicide Rice seedlings, five leaf stage were treated with 500 ppm fungicides for 2 days by infiltration through their roots. Intact leaves of cucumber seedlings, one leaf stage were treated with $50 \mathrm{ppm}$ Th-M by injection using an injector to tissues beneath the lower epidermal cell layer. In another experiments, $500 \mathrm{ppm}$ Th-M or $\mathrm{MBC}$ was sprayed on leaves of seedlings or poured into soil in pot.

Observation The inner epidermis with 2-3 cell layers of rice leaf sheath or the lower epidermis of cucumber leaves was peeled away by using a razor blade and observed under a microscope. For the observation of invaded hyphae of C. lagenarium, the pieces of cucumber leaves were fixed in formalin-acetic acid-ethanol solution and dehydrated through ethanol-butanol series solution. They were embedded in paraffin, then sectioned in $10 \mu \mathrm{m}$ width. Sections were stained in hematoxyline and eosine, gentian violet and acid fuchsine solution. For germination test, collodion solution was dropped on the inoculated leaves and the dried collodion membrane was peeled away from the surface and stained with cotton blue. Plasmolysis in rice leaf sheath cells was observed after staining with $0.2 \%$ neutral red solution and dipping in $1 \mathrm{M} \mathrm{KNO}_{3}$ solution.

\section{Results}

The germinated spore of $P$. oryzae formed appressorium on the surface of inner leaf sheath not treated with fungicide and also vegetative hypha developed in the invaded cells. Thereafter, the leaf sheath cells were occupied with hypha which further invaded into neighboring cells about 54 hours after inoculation (Plate I, 1). In treated sheath, it was observed that Th-M and MBC suppressed the formation of infection hypha and almost completely inhibited the growth of invading hypha (Plate I, 2), although spore germination was scarcely inhibited and appressorium formation was occasionally suppressed in some degree at the same hours after inoculation. When P. oryzae spores contacted with $500 \mathrm{ppm}$ Th-M on rice leaf sheath, the swollen or breaked spores and the distorted germ tubes were found (Plate I, 4-7) as observed in vitro ${ }^{9}$. On the other hand, the sheath cells treated with Th-M revealed convex plasmolysis (Plate I, 3), whereas the cells invaded with mycelia 50 hours after inoculation did not show any plasmolysis phenomenon.

Most of spores of C. lagenarium germinated and formed appressorium on the cucumber leaves treated with $500 \mathrm{ppm}$ Th-M or $\mathrm{MBC}$, as well as on untreated leaves or glass slide 24 hours after inoculation as shown in Table 1 . In this case, any morphological abnormality of germ tube or appressorium on treated leaves was not observed. The rate of penetration through appressorium of C. lagenarium into untreated host cells was $65 \% 96$ hours after inoculation (Table 2). In this infection stage, penetration peg mostly might grow to hyphae which extended and branched profusely in the palisade and spongy parenchyma cells ${ }^{11)}$ (Plate II, 1). In treated leaves, infection hyphae which derived from appressorium was never detected (Table 2 and Plate II, 2). The epidermal cell wall beneath the appressorium formed on treated leaves did not exhibited any abnormality, such as swelling, thickening or callosity formation ${ }^{1,2}$. 
Table 1. Effects of $500 \mathrm{ppm}$ Th-M and MBC on spore germination and appressorium formation of $C$, lagenarium on cucumber leaves treated 4 days before inoculation

\begin{tabular}{clccc}
\hline Fungicide & \multicolumn{1}{c}{ Treatment } & $\begin{array}{c}\text { Number of } \\
\text { spores } \\
\text { counted }\end{array}$ & $\begin{array}{c}\text { \% of spore } \\
\text { germination }\end{array}$ & $\begin{array}{c}\text { \% of appresso- } \\
\text { rium formation }\end{array}$ \\
\hline \multirow{2}{*}{ Th-M } & sprayed on leaves & 492 & 82 & 100 \\
& poured into soil in pot & 449 & 82 & 100 \\
MBC & sprayed on leaves & 505 & 72 & 100 \\
& poured into soil in pot & 433 & 85 & 100 \\
Untreated leaves & & 533 & 94 & 99 \\
\hline
\end{tabular}

Table 2. Effects of $500 \mathrm{ppm}$ Th-M and $\mathrm{MBC}$ on the invasion of $C$. lagenarium to the epidermal cells of cucumber leaves sprayed 4 days before inoculation

\begin{tabular}{ccc}
\hline Fungicide & $\begin{array}{c}\text { Number of appressoria } \\
\text { counted }\end{array}$ & $\begin{array}{c}\% \text { of the invasion to host } \\
\text { epidermal cells }\end{array}$ \\
\hline Th-M & 1,444 & 0 \\
MBC & 1,026 & 0 \\
Untreated & 1,309 & 65 \\
\hline
\end{tabular}

A network of superficial mycelia of $S$. fuliginea was produced on the lower surface of untreated leaves 4 days after inoculation (Plate II, 3). The growth of germ tubes of the germinated spores was inhibited by the treatment of the host plants with $50 \mathrm{ppm}$ Th-M (Plate II, 4), suggesting that the haustorium formation in host cell was suppressed and thereby aerial mycelia on leaf surface could not grow as in the dissimilar way as in untreated leaves.

\section{Discussion}

Appressorium formation of $P$. oryzae was not easily affected by the treatment of the host plants with Th-M or MBC. The germinated spore of C. lagenarium formed appressorium on treated leaves even at the concentration that could completely prevent the occurrence of symptom and exhibit strong antifungal activities against many fungi including $C$. lagenarium by agar dilution method4). On the other hand, these fungicides inhibited completely the hyphal growth of $P$. oryzae and $C$. lagenarium in treated respective host cells. Th-M also suppressed the development of superficial mycelia of $S$. fuliginea. Here inhibition is thought to attribute to preventing the formation of a globose haustorium by which the fungus obtains its nutrients. Thus, it may be concluded that the limitation of infection of pathogenic fungi by Th-M or MBC ascribes rather to suppressed the formation of infection peg or haustorium than to inhibition of spore germination and appressorium formation. In the present experiments, no difference between the effect of Th- $\mathrm{M}$ and $\mathrm{MBC}$ was observed in the infection process of $P$. oryzae and $C$. lagenarium, although $\mathrm{MBC}$ has more effective fungitoxicity than that of Th-M in vitro ${ }^{10,12)}$.

In the case of contact with $P$. oryzae spores on rice leaf sheath, Th-M and MBC occasionally caused the swelling or breakage of spore and the distortion of germ tubes. Yasuda $e t$ al9) reported that ${ }^{14} \mathrm{C}-\mathrm{Th}-\mathrm{M}$ was incorporated concurrently with spore germination and development of germ tubes 
and mainly accumulated at the abnormal regions in organ of $P$. oryzae. Th-M was converted in plants ${ }^{6)}$ and fungi ${ }^{10)}$ into MBC responsible for the fungitoxic effect ${ }^{12}$. Whether or not this characteristic phenomenon was attributed to fungitoxicity of $\mathrm{MBC}$ could not be confirmed in the present experiments. On the other hand, Th-M-treated rice leaf sheath cells revealed normal convex plasmolysis, and the epidermal cell wall of treated cucumber leaves beneath the appressoria did not exhibited any morphological abnormalities ${ }^{1,2)}$. These may indicate that Th-M never cause phytotoxicity to rice leaf sheath and cucumber leaves at the concentration that suppressed the formation of hyphae 3 ).

From the present observations, it was suggested that $\mathrm{Th}-\mathrm{M}$ has the possible fungitoxic actions as follows; (1) This fungicide cause the swelling or breakage of spore itself when it was directly contact with fungi at sufficient doses. (2) It also causes abnormal phenomenon on germ tubes or acts on the growing tip of germ tube and then affects appressorium formation or aerial mycelium development. (3) Even when appressoria were mostly formed, this fungicide inhibits characteristically the formation of penetration peg or hypha, thus preventing spread of invaded hypha in epidermal cells. It can be presumably concluded that Th-M acts mainly on process of penetration and not on prepenetration phase in some fungal infections.

\section{Literature cited}

1. Adams, P. B., Sproston, T., Tietz, H. and Major, R. T. (1962). Phytopathology 52: 233-236.

2. Akai, S., Horino, O., Fukutomi, M., Nakata, A., Kunoh, H. and Shiraishi, M. (1971). In Morphological and Biochemical Events in Plant-Parasite Interaction (Akai, S. and Ouchi, S., eds.). The Phytopath. Soc. Japan, Tokyo, pp. 329-344.

3. Hosotsuji, T., Kikkawa, K. and Wakai, A. (1969). Ann. Phytopath. Soc. Japan 35 : 358 (abstr.).

4. Hosotsuji, T., Yasuda, Y., Hashimoto, S. and Noguchi, T. (1970). Ibid. 36 : 197 (abstr.).

5. Ishii, K. (1970). In summaries of papers of 7 th International Congress of Plant Protection. Scientific commitee of this congress, Paris, pp. 200.

6. Noguchi, T., Ohkuma, K. and Kosaka, S. (1971). Int. Symp. on Pesticide Terminal Residue, Tel Aviv, Feb. 1971.

7. Sakamoto, M. (1968). Jubilee Pub. in Commemoration of 60th Birthday of Prof. M. Sakamoto: $1-139$.

8. Soeda, Y., Kosaka, S. and Noguchi, T. (1972). Agr. Biol. Chem. 36: 819-825.

9. Yasuda, Y. and Noguchi, T. (1972). Ann. Phytopoth. Soc. Japan 38: 252-253.

10. Yasuda, Y. Hashimoto, S., Soeda, Y. and Noguchi, T. (1973). Ibid. 39: 49-52.

11. Yasumori, H. (1957). Ibid. 22 : 119-122.

12. Vonk, K. W. and Sijpesteijn, A. K. (1971). Pesti. Science 2: 160-164.

\section{和文摘要}

数種の植物病原菌の感染過程におよぼす チオファネートーメチルの作用

安田康・中田昭・野口照久

新殺菌剂, チオファネートーメチル(Th-M) のイネいもち病菌 (Pyricularia oryzae), キュウリ炭疽病菌 (Colletotrichum lagenarium) およびキニウリらどんこ病菌 (Sphaerotheca fuliginea) の感染過程におよぼす 作用を光学顕徽鏡観察により追究した。

Th-M $(500 \mathrm{ppm})$ 処理葉上での P. oryzae や C. lagenarium の胞子発芽および附着器形成は阻止されな いが,同葉内への侵入杀の形成あるいはその生育が完全に抑えられた。また Th-M は 50 ppmでもS. fuliginea 
のキュウリ葉上での菌系の伸長を強く抑え，吸器の形成を阻止するようであった。一方，500 ppm の Th-M を イネ葉鞘上で P. oryzae の胞子と接触させた場合, Th-M は胞子自身の細胞を膨張させたりあるいは破かいし, また発芽管の先端を彎曲した。他方，処理イネ葉鞘細胞は正常な原形質分離能を有し，また処理キ二ウリ葉の表 皮細胞の細胞壁には形態的な異常は見られなかった。

Th-M の主な代謝産物である MBC は侵入糸の生育を阻止したが，感染過程におよぼす Th-M と MBC の作用の差異は認められなかった。これらの殺菌剂の特徵は寄主葉上の胞子発芽や附着器形成に対するよりもむ しろ，病原菌の侵入過程に主に作用する点にあることが結論された。

\section{Plate I.}

\section{Explanation of plates}

1. Appressorium (A) of Pyricularia oryzae and hyphae $(\mathrm{H})$ developed in inner epidermal cell of rice leaf sheath 54 hours after inoculation.

2. Appressorium (A) of P. oryzae spore (S) formed on inner epidermal cells of $500 \mathrm{ppm}$ Th-M-treated sheath. Inner hyphal growth was suppressed.

3. Plasmolysis shown in $500 \mathrm{ppm}$ Th-M-treated sheath cells.

4. and 5. Distorted germ tubes (arrows) of P. oryzae spores on $500 \mathrm{ppm}$ Th-M-treated sheath cells.

6. and 7. Swollen (Sw) and breaked (B) spores of P. oryzae on $500 \mathrm{ppm}$ Th-M-treated sheath cells.

\section{Plate II.}

1. Appressorium (A) of Colletotrichum lagenarium and infection hyphae $(\mathrm{H})$ grown in cucumber leaves 3 days after inoculation.

2. Appressorium (A) of C. lagenarium on $500 \mathrm{ppm}$ Th-M-treated leaves of cucumber. No infection hyphae was observed.

3. A network of aerial mycelium (M) produced on the lower surface of epidermis of cucumber leaves 4 days after inoculation with Sphaerotheca fuliginea spore (S).

4. The suppressed growth of germ tubes $(\mathrm{G})$ of $S$. fuliginea spore (S) on the surface of $50 \mathrm{ppm}$ Th-M-treated cucumber leaves 5 days after inoculation. 
Plete I

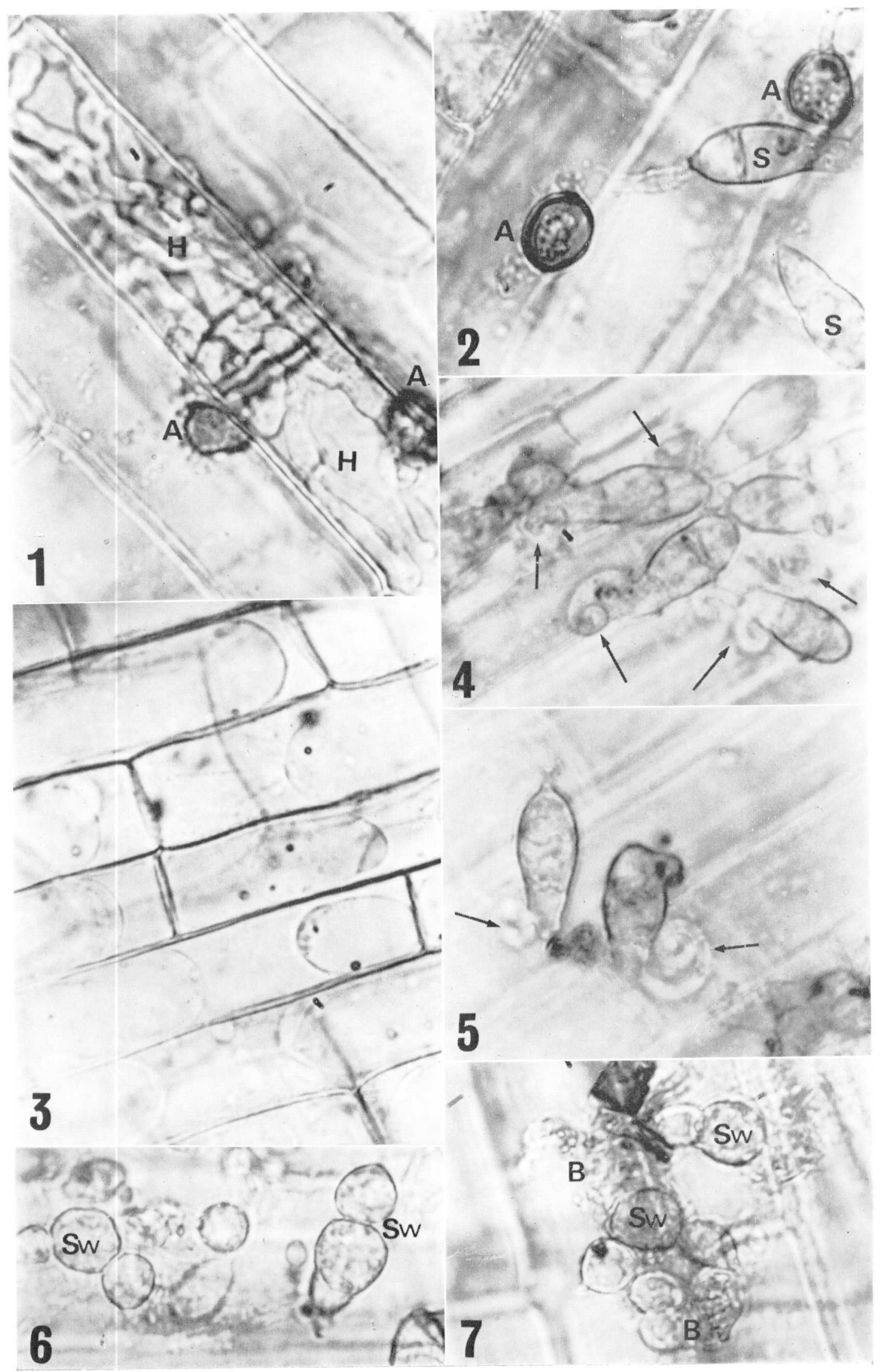


Plete II

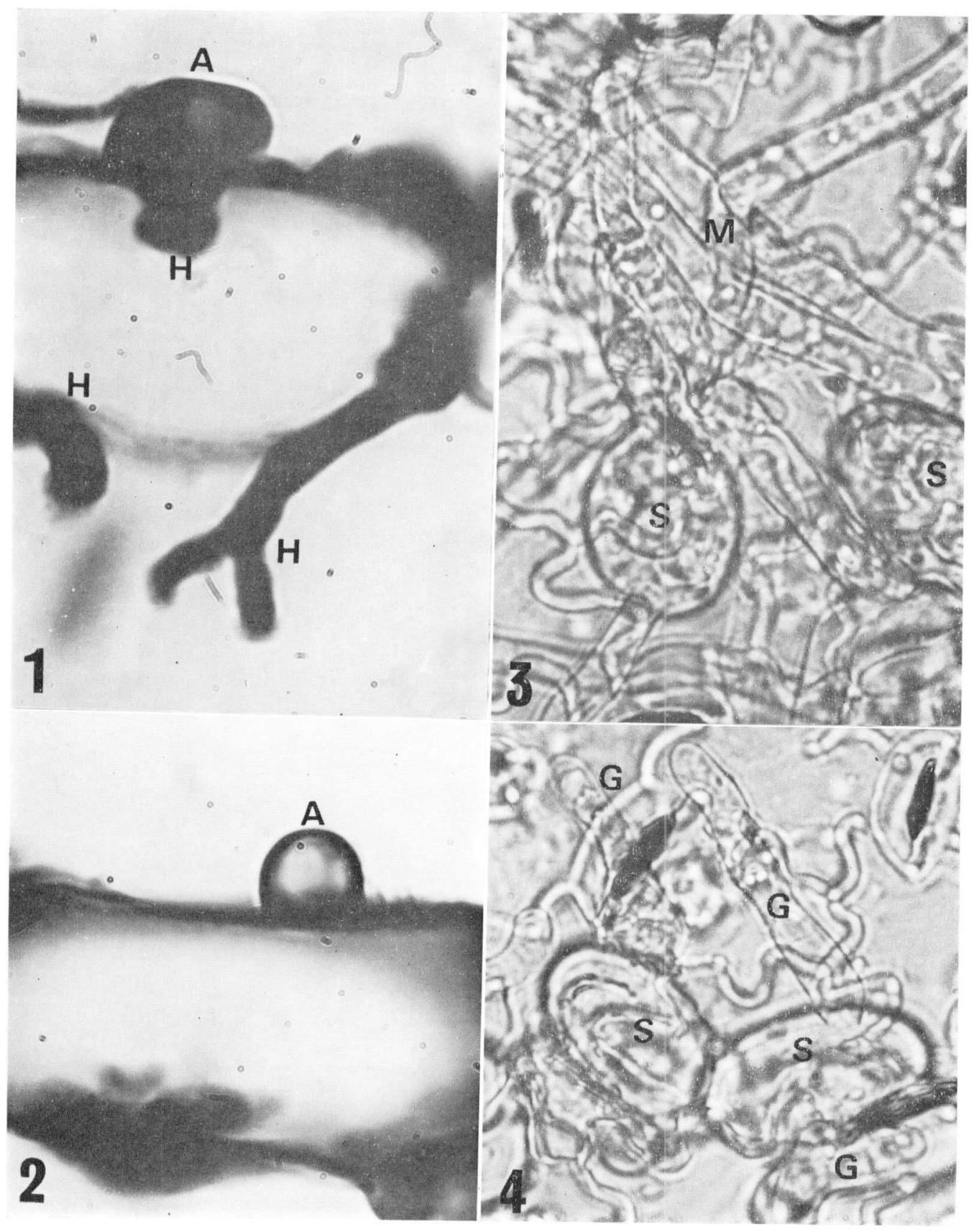

